\title{
Communication
}

\section{Perovskite hollow nanospheres for the catalytic wet air oxidation of lignin}

\author{
Peng Gao a,b, Changzhi Li a , Hua Wang a , Xiaodong Wang a , Aiqin Wang a,* \\ a State Key Laboratory of Catalysis, Dalian Institute of Chemical Physics, Chinese Academy of Sciences, Dalian 116023, Liaoning, China \\ b University of Chinese Academy of Sciences, Beijing 100049, China
}

\section{A R T I C L E I N F O}

\section{Article history:}

Received 10 July 2013

Accepted 16 August 2013

Published 20 October 2013

Keywords:

Perovskite-type oxide

Lignin

Catalytic wet air oxidation

High catalytic activity

Low leaching

\section{A B S T R A C T}

A urea-assisted solvothermal-calcination method was used to prepare $\mathrm{LaFe}_{x} \mathrm{Mn}_{1-x} \mathrm{O}_{3}$ and $\mathrm{La}_{0.9} \mathrm{Sr}_{0.1} \mathrm{MnO}_{3}$ hollow nanospheres, and their crystal phase, morphology, and specific surface area properties were analyzed by X-ray diffraction, transmission electron microscopy, and nitrogen adsorption-desorption isotherms. These materials were then evaluated as catalysts for the catalytic wet air oxidation (CWAO) of lignin, and showed much better catalytic performance than perovskite prepared by the traditional sol-gel method. The structure of the hollow nanospheres has been suggested as the reason of this higher catalytic activity. For the CWAO reaction at $120^{\circ} \mathrm{C}$ and $0.2 \mathrm{MPa}$ $\mathrm{O}_{2}$, the conversion of lignin was greater than $80 \%$ after $1 \mathrm{~h}$. Analysis of the ions leaching from the material following the completion of the reaction showed that the catalysts were very stable under the reaction conditions because of their perovskite phase structure.

(C) 2013, Dalian Institute of Chemical Physics, Chinese Academy of Sciences. Published by Elsevier B.V. All rights reserved.
Fossil fuels have been used by humans for thousands of years. With an increasing sense of sustainability, it has been realized that non-renewable resources, such as coal and oil, will be completely exhausted at some point in the future, and that the development of alternative energy sources is therefore urgently required. As a renewable and abundant recourse that can be used to produce energy and fuels, biomass has thus become the focus of intense research activity in recent years [1-3]. Lignin is an important component of biomass and has a natural reserve ranking that is second only to cellulose. Globally, plants produce about 50 billion tons of lignin a year by photosynthesis. The main industrial source of lignin is the effluent from paper manufacturing, which provides about 50 million tons of lignin every year. To date, however, only a limited amount of lignin has been efficiently used with only $5 \%$ of the lignin potentially available being used in commercial applications of low value, such as concrete additive [4] or low-grade fuel [5]. In most developing countries, lignin is still a wasted resource, which is directly discharged or even burnt. From the perspectives of environment concern and energy efficiency, the effective conversion of lignin is of great significance.

Lignin is a natural polymer composed predominantly of three primary units, including 4-propyl-phenol, 2-methoxy-4propyl-phenol, and 2,6-dimethoxy-4-propyl-phenol. These three so-called "monolignols" are also known as p-hydroxyphenyl $(H)$, guaiacyl $(G)$, and syringyl (S) units, respectively. These three units can be converted to the three aromatic aldehydes vanillin, syringaldehyde and $p$-hydroxybenzaldehyde, respectively, which are widely used to manufacture food additives, deodorants, air fresheners, herbicides, and pharmaceuticals [6-8]. Researchers working with lignin generally consider catalytic wet air oxidation (CWAO) to be a good method for the oxidation decomposition of lignin. This method has several advantages, including mild conditions, good selectivity, and

\footnotetext{
*Corresponding author. Tel: +86-411-84379348; Fax: +86-411-84685940; E-mail: aqwang@dicp.ac.cn This work was supported by the National Natural Science Foundation of China (21003121 and 21076211). 
short reaction times $[9,10]$. The products of lignin CWAO can either be categorized as gases, liquids, or solids. The gas products generally consist of $\mathrm{CO}, \mathrm{CO}_{2}$, and a variety of different hydrocarbons, whereas the solid product is mainly char adhering to the surface of the catalyst. In contrast, the liquid products generally consist of small organic molecules (e.g., formic acid, acetic acid, formaldehyde, and acetaldehyde), monomeric aromatic aldehydes, and oligomers. Among the latter two, aromatic aldehydes are considered to be high value-added chemicals, while oligomers also possess considerable economic value as fuel additives [11,12].

Among the catalysts for CWAO reactions, noble metal and transition metal-based catalysts have been the most widely studied. Deng et al. [13-15] recently prepared perovskite-type oxides (with the chemical formula $\mathrm{ABO}_{3}$ ) using the citric acid sol-gel method and suggested that these $\mathrm{ABO}_{3}$ materials could potentially be used as catalysts for the CWAO of lignin. Compared with the high cost of noble metals and collateral contaminations caused by transition metal ions, the affordability and stability properties of perovskites have placed them in a promising position in terms of their potential application for the conversion of lignin. This particular type marterials, however, are usually prepared via processes that involve hightemperature crystallization stages, which can lead to a significant reduction in the specific surface area. In our previous work [16], a urea-assisted solvothermal method was developed to synthesize perovskite-type hollow nanospheres. These materials with relatively high specific areas and excellent mass transfer properties are highly effective for the CWAO of phenol. In this study, we prepared a series of $\mathrm{LaFe}_{1-x} \mathrm{Mn}_{x} \mathrm{O}_{3}$ (nominally, $x=$ $0,0.25,0.5,0.75,1.0$ ) and $\mathrm{La}_{0.9} \mathrm{Sr}_{0.1} \mathrm{MnO}_{3}$ hollow nanospheres using a similar method. The resulting materials were evaluated as catalysts for the CWAO of lignin, and the results showed that both types of material provided high catalytic performances and stability.

All of the reagents used were purchased as the analytical reagent grade. The method used to synthesize the hollow nanospheres was described in our previous publication [16]. Briefly, ethanol $(2 \mathrm{~mL}), \mathrm{H}_{2} \mathrm{O}(2 \mathrm{~mL})$, and ethylene glycol ( $\left.8 \mathrm{~mL}\right)$ were mixed to form a ternary solvent system, and then citric acid $\left(\mathrm{C}_{6} \mathrm{H}_{8} \mathrm{O}_{7} \cdot \mathrm{H}_{2} \mathrm{O}, 10 \mathrm{mmol}\right)$, urea (45 mmol), and P123 (1.0 g) were added, followed by $\mathrm{La}\left(\mathrm{NO}_{3}\right)_{3} \cdot 6 \mathrm{H}_{2} \mathrm{O}(\mathrm{LN}), \mathrm{Fe}\left(\mathrm{NO}_{3}\right)_{3} \cdot 9 \mathrm{H}_{2} \mathrm{O}$ $(\mathrm{FN}), \mathrm{Sr}\left(\mathrm{NO}_{3}\right)_{2}(\mathrm{SN})$, and $50 \mathrm{wt} \% \mathrm{Mn}\left(\mathrm{NO}_{3}\right)_{2}$ solution $(\mathrm{MN})$ as listed in Table 1. The resulting mixture was then stirred for $5 \mathrm{~h}$ at room temperature before being transferred into a $70 \mathrm{~mL}$ autoclave and heated at $100{ }^{\circ} \mathrm{C}$ for $48 \mathrm{~h}$. The precursors ob-

\section{Table 1}

Nominal formulas and abbreviations of the PHSs materials and the corresponding amounts of the nitrate reactants.

\begin{tabular}{lccccc}
\hline \multirow{2}{*}{ Nominal formula } & \multirow{2}{*}{ Abbreviation } & \multicolumn{4}{c}{ Amounts of nitrate reactants (g) } \\
\cline { 3 - 6 } & LFHS & 1.08 & 0 & 1.01 & 0 \\
\hline $\mathrm{LaFeO}_{3}$ & LFMHS-1 & 1.08 & 0 & 0.75 & 0.56 \\
$\mathrm{LaFe}_{0.75} \mathrm{Mn}_{0.25} \mathrm{O}_{3}$ & LFMHS-2 & 1.08 & 0 & 0.50 & 1.12 \\
$\mathrm{LaFe}_{0.5} \mathrm{Mn}_{0.5} \mathrm{O}_{3}$ & LFMHS-3 & 1.08 & 0 & 0.25 & 1.68 \\
$\mathrm{LaFe}_{0.25} \mathrm{Mn}_{0.75} \mathrm{O}_{3}$ & LMHS & 1.08 & 0 & 0 & 2.28 \\
$\mathrm{LaMnO}_{3}$ & LSMHS & 0.97 & 0.05 & 0 & 2.28 \\
$\mathrm{La}_{0.9} \mathrm{Sr}_{0.1} \mathrm{MnO}_{3}$ & & & & &
\end{tabular}

tained were subsequently washed sequentially with deionized water and absolute ethanol before being centrifuged at 12000 $x g$ for $10 \mathrm{~min}$ and then dried in an oven at $60^{\circ} \mathrm{C}$. The resulting dried precursors were then grounded and calcined at $600{ }^{\circ} \mathrm{C}$ for $4 \mathrm{~h}$, with a temperature ramp of $0.5^{\circ} \mathrm{C} / \mathrm{min}$ to produce the perovskite hollow nanospheres (denoted as PHSs hereafter). For comparison, we also used a traditional citric acid method to prepare $\mathrm{LaMnO}_{3}$ (CALM) material.

A Tecnai G2 Spirit electron microscope (FEI, USA) was used to record transmission electron microscope (TEM) images of the materials. A PANalytical X'Pert PRO powder X-ray diffractometer (the Netherlands) was used to record the powder X-ray diffraction (XRD) patterns of the materials using $\mathrm{Cu} K_{\alpha}$ radiation. A Micromeritics ASAP 2010 apparatus (USA) was used to obtain the $\mathrm{N}_{2}$ adsorption-desorption isotherms of the materials, and the Brunauer-Emmett-Teller (BET) method was used to calculate the specific surface areas. An inductively coupled plasma optical emission spectrometer (ICP-OES, IRIS Intrepid II XSP, Thermo, USA) was used to determine the $\mathrm{La} / \mathrm{Fe} / \mathrm{Mn} / \mathrm{Sr}$ ratios of the materials synthesized. Thermogravimetric (TG) analyses were conducted on a SETSYS 16/18 thermal analyzer (SETARAM, France).

Lignin samples were obtained by the alkali extraction of the solid residue derived from the hydrochloric acid catalyzed hydrolysis of corn stalks [17]. Prior to the oxidation reaction, lignin was dissolved in $\mathrm{NaOH}$ solution ( $2 \mathrm{~mol} / \mathrm{L})$ at a concentration of $10 \mathrm{~g} / \mathrm{L}$. A portion $(20 \mathrm{~mL})$ of the resulting lignin solution was then loaded into a 70-mL stainless steel autoclave together with $0.02 \mathrm{~g}$ of the catalysts $(1 \mathrm{~g} / \mathrm{L})$. The autoclave was then purged before being filled with $\mathrm{O}_{2}$ to an initial pressure of 0.2 MPa. Under a fixed stirring rate, the reactor was heated to 100 ${ }^{\circ} \mathrm{C}$ within $30 \mathrm{~min}$ and then heated to $120{ }^{\circ} \mathrm{C}$ within $30 \mathrm{~min}$. The temperature was then held at $120^{\circ} \mathrm{C}$ for 1 or $2 \mathrm{~h}$.

Upon completion of the CWAO reactions, the product solutions were centrifuged at $12000 \times g$ for $10 \mathrm{~min}$ to separate the catalysts, which were used for TG analysis to determine the yield of char. The $\mathrm{pH}$ values of the solutions were then adjusted using concentrated $\mathrm{HCl}$ to $\mathrm{pH} 1-2$. The solutions were then extracted with chloroform to extract the products (aromatic aldehydes), until the chloroform layer became colorless. The solutions were then centrifuged again, and the resulting liquid supernatants were analyzed by ICP-OES to investigate the extent of any leaching from the hollow nanospheres, before being evaporated to dryness to allow for the dry weight of the oligomers to be determined. The combined extracts were treated with $\mathrm{NaHCO}_{3}$ and dried with anhydrous $\mathrm{Na}_{2} \mathrm{SO}_{4}$ before being diluted with chloroform to $50 \mathrm{~mL}$. An Agilent Varian 320-MS TQ mass spectrometer (USA) was used to analyze the products. An Agilent 6890N Network Gc System gas chromatography system (USA) equipped with a HP-5 column (30 $\mathrm{m} \times 0.32 \mathrm{~mm} \times$ $0.25 \mu \mathrm{m}$ ) was used to determine the quantity of vanillin, $C_{\text {vanillin }}$ $(\mathrm{g} / \mathrm{L})$. Given that $c_{\text {lignin }}=10 \mathrm{~g} / \mathrm{L}$, the yield of vanillin can be calculated as follows:

$$
\begin{gathered}
\text { Yield }_{\text {vanillin }}=\left(c_{\text {vanillin }} \times 50 \mathrm{~mL} / c_{\text {lignin }} \times 20 \mathrm{~mL}\right) \times 100 \% \\
=0.25 c_{\text {vanillin }} \times 100 \%
\end{gathered}
$$

A total organic carbon (TOC) analyzer (Elementar) was used to determine the other catalytic parameters. Thus, on the basis 


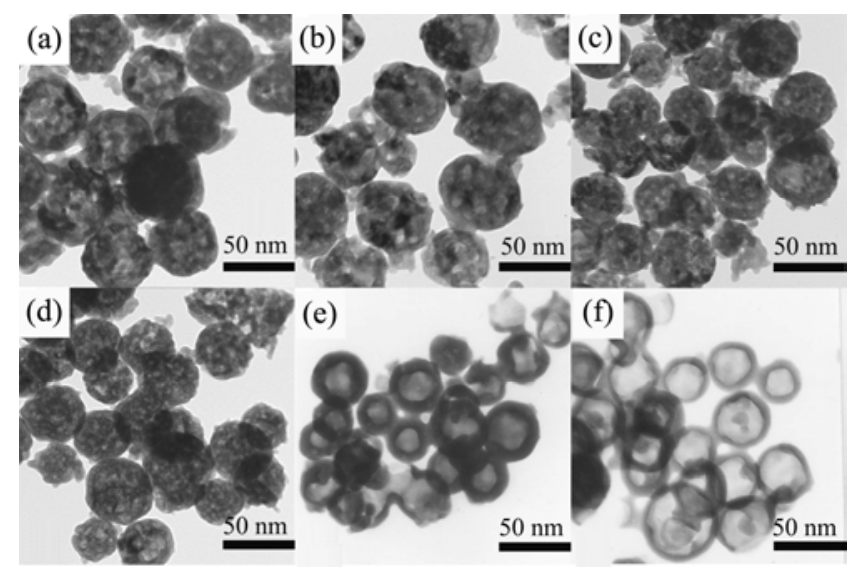

Fig. 1. TEM images of LFHS (a), LFMHS-1 (b), LFMHS-2 (c), LFMHS-3 (d), LMHS (e), and LSMHS (f) samples.

of lignin, the following data is obtained:

$$
\begin{aligned}
\text { Yield }_{\text {gas }} & =\left(1-\mathrm{TOC}_{1} / \mathrm{TOC}_{0}\right) \times 100 \% \\
\text { Yield }_{\text {liquid }} & =\mathrm{TOC}_{2} / \mathrm{TOC}_{0} \times 100 \% \\
\text { Conversion }_{\text {lignin }} & =\left(1-\left(\mathrm{TOC}_{1}-\mathrm{TOC}_{2}\right) / \mathrm{TOC}_{0}\right) \times 100 \%
\end{aligned}
$$

The TEM images of the PHSs materials demonstrated that they were perovskite-type oxides with the morphology of hollow nanospheres (Fig. 1), which would have been formed by the assembly of primary nanoparticles [16]. All of the PHSs materials possessed a diameter of about $50 \mathrm{~nm}$, while XRD characterization (Fig. 2) results indicated that these samples could be assigned as cubic perovskite (ICSD no. 029119, LaM$\mathrm{nO}_{3}$ space group: $\mathrm{Pm}-3 m, a=38.8 \mathrm{~nm}$ ). The specific surface areas and $\mathrm{La} / \mathrm{Fe} / \mathrm{Mn} / \mathrm{Sr}$ ratios of the materials are listed in Table 2. The results showed that the PHSs materials had a much higher specific surface areas than CALM prepared by traditional citric acid method. Furthermore, the La/Fe/Mn/Sr ratios were slightly different from the nominal ratios because of the distribution of citrate complexes of cations [18].

Upon completion of the reaction, analysis by mass spectrometry revealed the presence of several by-products resulting from the decomposition of lignin during the CWAO reaction. There are five major products in the liquid phase (Fig. 3), including vanillin (G), syringaldehyde $(\mathrm{S}), p$-hydroxybenzaldehyde $(H)$, acetovanillone $(G)$, and acetosyringone $(S)$. These

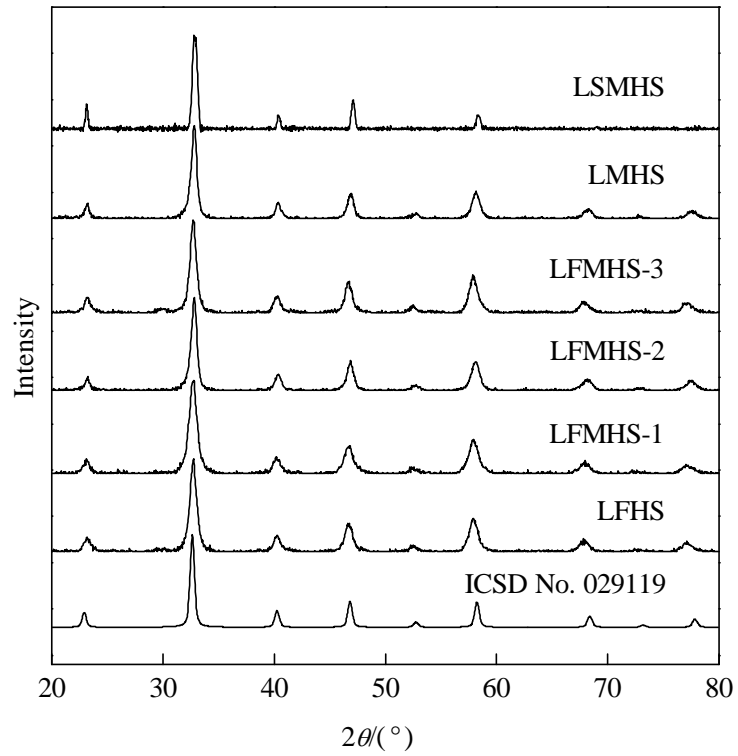

Fig. 2. XRD patterns of PHSs samples.

Table 2

Actual $\mathrm{La} / \mathrm{Sr} / \mathrm{Fe} / \mathrm{Mn}$ ratios and specific surface areas of the PHSs materials.

\begin{tabular}{lcc}
\hline Sample & Actual ratio of La/Sr/Fe/Mn & $A_{\text {BET }}\left(\mathrm{m}^{2} / \mathrm{g}\right)$ \\
\hline LFHS & $1 / 0 / 0.98 / 0$ & 26.3 \\
LFMHS-1 & $1 / 0 / 0.68 / 0.32$ & 25.9 \\
LFMHS-2 & $1 / 0 / 0.45 / 0.55$ & 25.2 \\
LFMHS-3 & $1 / 0 / 0.16 / 0.84$ & 28.2 \\
LMHS & $1 / 0 / 0 / 1.01$ & 30.8 \\
LSMHS & $1 / 0.03 / 0 / 1.02$ & 31.2 \\
CALM & $1 / 0 / 0 / 1$ & 8.6 \\
\hline
\end{tabular}

compounds were clearly the oxidation products of the $\mathrm{G}, \mathrm{S}$, and $\mathrm{H}$-type primary units. It thus is clear that corn stalk lignin consists of a mixture of all three aromatic primary units, which is in agreement with the composition of grass lignin [19]. The mechanism of this reaction is believed to be similar to that proposed by Deng et al $[13,14]$ because the catalysts used are both perovskite-type oxides.

Among these products, vanillin is the most valuable one and was picked as the target product for quantitative analysis. The lignin conversion levels and the yields of the oligomers were<smiles>CCCc1ccc(Oc2cc(OCCCCCc3cc(OC)c(O)c(OC)c3)ccc2CCC)cc1OC</smiles><smiles>COc1cc(C=O)ccc1O</smiles>

Vanillin (H)<smiles>COc1cc(C=O)cc(OC)c1O</smiles><smiles>COc1cc(C(C)=O)ccc1O</smiles>

Syringaldehyde (S) Acetovanillone (H)<smiles>O=Cc1ccc(O)cc1</smiles><smiles>COc1cc(C(C)=O)cc(OC)c1O</smiles>

Fig. 3. Main products of lignin CWAO detected by mass spectroscopy. 
Table 3

Lignin conversion results and product yields over the different catalysts.

\begin{tabular}{|c|c|c|c|c|c|c|}
\hline \multirow{2}{*}{ Catalyst } & \multirow{2}{*}{$\begin{array}{c}\text { Lignin } \\
\text { conversion } \\
(\%) \\
\end{array}$} & \multicolumn{4}{|c|}{ Yield (\%) } & \multirow{2}{*}{$\begin{array}{l}\text { Cation } \\
\text { leaching } \\
\text { (ppm) }\end{array}$} \\
\hline & & Gas & Oligomer & Vanillin & Char & \\
\hline Blank & 32.0 & 7.1 & 13.5 & 1.2 & - & - \\
\hline LFHS & 84.8 & 17.9 & 38.1 & 2.9 & 1.1 & 4.8 \\
\hline LFMHS-1 & 87.2 & 16.7 & 38.6 & 2.6 & 1.1 & 4.3 \\
\hline LFMHS-2 & 87.3 & 21.0 & 37.6 & 2.8 & 1.1 & 4.4 \\
\hline LFMHS-3 & 86.0 & 19.8 & 36.4 & 2.8 & 1.1 & 4.6 \\
\hline LMHS & 84.5 & 22.0 & 37.2 & 2.8 & 1.1 & 4.2 \\
\hline LSMHS & 84.6 & 23.4 & 34.1 & 3.0 & 1.1 & 4.3 \\
\hline CALM & 46.1 & 13.1 & 15.1 & 1.5 & 1.4 & 3.1 \\
\hline LMHS a & 93.1 & 22.8 & 42.6 & 3.4 & 1.1 & 4.7 \\
\hline CALM $^{a}$ & 54.5 & 12.4 & 17.2 & 1.9 & 1.4 & 3.4 \\
\hline
\end{tabular}

Reaction conditions: $0.2 \mathrm{MPa} \mathrm{O}_{2}, 120^{\circ} \mathrm{C}$ for $1 \mathrm{~h}(\mathrm{a} 2 \mathrm{~h}$ ).

b The total leaching concentration of all cations, i.e. $c\left(\mathrm{La}^{3+}+\mathrm{Sr}^{2+}+\mathrm{Fe}^{3+}+\right.$ $\left.\mathrm{Mn}^{2+}\right)$.

also taken into account. Table 3 shows the lignin conversions and yields of the different products over each catalyst. Under typical CWAO conditions $\left(120^{\circ} \mathrm{C}\right.$ for $\left.1 \mathrm{~h}\right)$, CALM was found to be moderately active (with a lignin conversion of $46.1 \%$, which was almost 1.5-fold greater than the result obtained in the absence of the catalyst), whereas LMHS exhibited much higher activity (with a lignin conversion of $84.5 \%$ ). This was attributed to the higher specific surface areas and hollow nanosphere structures of the LMHS. The higher specific surface areas would provide a larger number of active sites, and therefore lead to an improvement in the catalytic activity of the material. Furthermore, the spherical shape of these particles represents the best configuration for mass transfer, which is critical for solid-liquid phase reactions under low temperature conditions, and leads to improved catalytic activity. With regard to oligomer yields, LMHS (37.2\%) also showed much higher activity over CALM (15.1\%). These liquid products have the potential to be converted to gasoline blending components, and could therefore also provide additional revenue [11].

It stands to reason that partly substituting the A or B cation with an $A^{\prime}$ or B' cation could enhance or reduce to some extent the activities of $\mathrm{ABO}_{3}$ catalysts. In the $\mathrm{LaFe}_{1-x} \mathrm{Mn}_{x} \mathrm{O}_{3}$ materials, however, the lignin conversion and the vanillin yields were almost identical, demonstrating that the tuning of the B site cation has little effect on the lignin conversion or the yield of vanillin in this case. Therefore, LMHS was selected as a model catalyst to investigate the impact factors of A site doping. From Table 3, it is also clear that the partial substitution of $\mathrm{La}^{3+}$ with $\mathrm{Sr}^{2+}$ had little impact on the lignin conversion $(84.5 \%$ vs $84.6 \%$ ) or vanillin yield ( $2.8 \%$ vs $3.0 \%$ ). Given the short reaction time, we conclude that the hollow nanosphere structure was the dominant factor, which outweighed the doping of the A or B site. This might explain why PHSs showed much higher catalytic activity than the conventionally prepared CALM.

The reaction time was also investigated in a preliminarily sense. When the reaction time was extended to $2 \mathrm{~h}$, the conversion of lignin over the typical LMHS catalyst reached $93.1 \%$, whereas it was only $54.5 \%$ over CALM sample. This was very similar to the previously reported figure (ca. 50\% conversion for $2 \mathrm{~h}$ over $\mathrm{LaFeO}_{3}$ prepared with citric acid method) [15], and provides further evidence of the high catalytic performance capabilities of PHS materials. Moreover, the yield of vanillin increased from $2.8 \%$ to $3.4 \%$, suggesting that the vanillin yield is a function of reaction time.

Following from the reaction and their subsequent chloroform extraction, the supernatant solutions were analyzed by ICP-OES, and the results are also listed in Table 3. For all of the perovskite-type oxide catalysts, including CALM, the total cation concentrations were quite low at less than $5 \mathrm{ppm}$, which reflects the stability of the catalysts. According to Yang et al. [20], low leaching property of the material could be attributed to its stable perovskite-type crystal structure. Furthermore, TEM result also showed that the morphological features of the hollow nanospheres had also been maintained after the reaction.

In conclusion, a series of $\mathrm{LaFe}_{1-\mathrm{x}} \mathrm{Mn}_{x} \mathrm{O}_{3}$ and $\mathrm{La}_{0.9} \mathrm{Sr}_{0.1} \mathrm{MnO}_{3}$ hollow nanospheres have been prepared and used in the CWAO of lignin, where they showed both good catalytic performances and excellent stability profiles. The hollow nanosphere structures of these catalysts are believed to be critical to their high catalytic activity in terms of active sites and mass transfer processes and have revealed a deeper understanding of CWAO reactions especially under low temperature conditions. Further studies of the $\mathrm{G} / \mathrm{H} / \mathrm{S}$ ratio are required to develop a much clearer understanding of the structural properties of different lignins. Detailed investigations of reaction and product kinetics are also needed to identify further opportunities for the utilization of lignin, and the beginning of a new era in alternative energy.

\section{References}

[1] Adler E. Wood Sci Technol, 1977, 11: 169

[2] Camarero S, Ibarra D, Martinez M J, Martinez A T. Appl Environ Microbiol, 2005, 71: 1775

[3] Jung H G. Forage Cell Wall Structure and Digestibility. Madison, Wisconsin: American Society of Agronomy, Crop Science Society of America, Soil Science Society of America, 1993. 133

[4] Doherty W O S, Mousavioun P, Fellows C M. Ind Crop Prod, 2011, 33: 259

[5] Hu L H, Pan H, Zhou Y H, Zhang M. BioResources, 2011, 6: 3515

[6] Ibrahim M N M, Sriprasanthi R B, Shamsudeen S, Adam F, Bhawani S A. BioResources, 2012, 7: 4377

[7] Walton N J, Mayer M J, Narbad A. Phytochemistry, 2003, 63: 505

[8] Yang H P, Yan R, Chen H P, Lee D H, Zheng C G. Fuel, 2007, 86: 1781

[9] Sales F G, Maranhao L C A, Lima Filho N M, Abreu C A M. Ind Eng Chem Res, 2006, 45: 6627

[10] Luck F. Catal Today, 1999, 53: 81

[11] Vigneault A, Johnson D, Chornet E. In: Di Blasi C. Science in Thermal and Chemical Biomass Conversion Conference. Victoria, BC: CPL Press, 2006. 1401

[12] Song Q, Cai J Y, Zhang J J, Yu W Q, Wang F, Xu J. Chin J Catal (宋奇, 蔡嘉芗, 张俊杰, 于维强, 王峰, 徐杰. 催化学报), 2013, 34: 651

[13] Deng H B, Lin L, Liu S J. Energy Fuels, 2010, 24: 4797

[14] Deng H B, Lin L, Sun Y, Pang C S, Zhuang J P, Ouyang P K, Li J J, Liu S J. Energy Fuels, 2009, 23: 19

[15] Deng H B, Lin L, Sun Y, Pang C S, Zhuang J P, Ouyang P K, Li J J. Chin 


\title{
Graphical Abstract
}

Chin. J. Catal., 2013, 34: 1811-1815 doi: 10.1016/S1872-2067(12)60691-3

\section{Perovskite hollow nanospheres for the catalytic wet air oxidation of lignin}

Peng Gao, Changzhi Li, Hua Wang, Xiaodong Wang, Aiqin Wang*

Dalian Institute of Chemical Physics, Chinese Academy of Sciences; University of Chinese Academy of Sciences

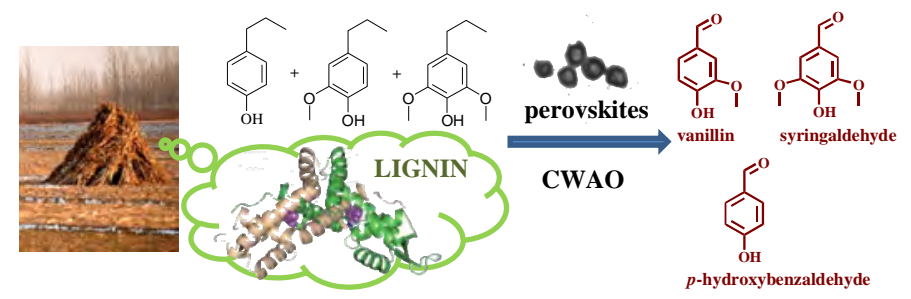

Perovskite hollow nanospheres have been used as catalysts for the CWAO of lignin, where they exhibited good catalytic activity and excellent stability, revealing a new application in biomass conversion.

J Catal 邓海波, 林鹿, 孙勇, 庞春生, 庄军平, 欧阳平凯, 李静江. 催化学报), 2008, 29: 753

[16] Gao P, Li N, Wang A Q, Wang X D, Zhang T. Mater Lett, 2013, 92: 173

[17] Moon S-J, Eom I-Y, Kim J-Y, Kim T-S, Lee S M, Choi I-G, Choi J W.
Bioresour Technol, 2011, 102: 5912

[18] Li X, Tang C J, Ai M, Dong L, Xu Z. Chem Mater, 2010, 22: 4879

[19] Zakzeski J, Bruijnincx P C A, Jongerius A L, Weckhuysen B M. Chem Rev, 2010, 110: 3552

[20] Yang X M, Chaki T K. Mater Sci Eng B, 1996, 39: 123

\section{用于木质素催化湿式氧化反应的纳米空心球钙钛矿催化剂}

\author{
高 鹏, ${ }^{\mathrm{a}, \mathrm{b}}$, 李昌志 ${ }^{\mathrm{a}}$, 王 华 ${ }^{\mathrm{a}}$, 王晓东 ${ }^{\mathrm{a}}$, 王爱琴 ${ }^{\mathrm{a}},{ }^{*}$ \\ $\mathrm{a}$ 中国科学院大连化学物理研究所, 辽宁大连 116023 \\ b国科学院大学, 北京100049
}

摘要: 利用尿素辅助溶剂热法合成了一系列 $\mathrm{LaFe}_{x} \mathrm{Mn}_{1-x} \mathrm{O}_{3}$ 和 $\mathrm{La}_{0.9} \mathrm{Sr}_{0.1} \mathrm{MnO}_{3}$ 纳米空心球材料, 并采用 $\mathrm{X}$ 射线衍射、透射电子显微镜 和物理吸附等方法对其晶相、形貌和比表面积进行了表征. 在木质素的催化湿式氧化反应(CWAO)中, 该催化剂表现出比传统的 柠檬酸溶胶-凝胶法制备的钲钛矿材料更高的催化活性. 这主要是由于空心球结构所致. 当 $T=120{ }^{\circ} \mathrm{C}, p\left(\mathrm{O}_{2}\right)=0.2 \mathrm{MPa}$ 时, $\mathrm{CWAO}$ 反应 $1 \mathrm{~h}$ 后木质素转化率超过 $80 \%$. 反应后组分离子溶出量很低, 表明由于钙钛矿相结构的存在, 催化剂在该反应条件下非常稳定. 关键词: 钲钛矿型氧化物; 木质素; 催化湿式氧化; 高催化活性; 低溶出值

收稿日期: 2013-07-10. 接受日期: 2013-08-16. 出版日期: 2013-10-20.

*通讯联系人. 电话: (0411)84379348; 传真: (0411)84685940; 电子信箱: aqwang@dicp.ac.cn

基金来源：国家自然科学基金(21003121, 21076211).

本文的英文电子版由Elsevier出版社在ScienceDirect上出版(http://www.sciencedirect.com/science/journal/18722067). 